\title{
Mewujudkan Sifat Zuhud Pada Mahasiswa Melalui Bimbingan Kelompok Berbasis Hadist
}

\author{
Zhila Jannati*, Muhammad Randicha Hamandia \\ Universitas Islam Negeri Raden Fatah, Indonesia \\ @zhila_jannati10@radenfatah.ac.id*
}

Submitted:
2020-05-17
Revised:
2020-08-04
Accepted:
$2020-09-06$
Copyright holder:
O Jannati, Z., \& Hamandia, R, H. (2020)
This article is under:
CCC
How to cite:
Jannati, Z., \& Hamandia, R, H (2020). Mewujudkan Sifat
Zuhud pada Mahasiswa Melalui Bimbingan Kelompok
Berbasis Hadist. Bulletin of Counseling and
Psychotherapy, 2(2).
Published by:
Kuras Institute
Journal website:
https://journal.kurasinstitute.com/index.php/bocp
E-ISSN: $2656-1050$

\begin{abstract}
Zuhud is a very important trait for individuals in dealing with a world that is so tiring and exhausting for humans. Zuhud will bring peace of mind and peace of mind. The purpose of this study was to find out how to realize the zuhud nature of students through hadith-based group guidance. This research uses a qualitative approach. The sample in this study was determined through a sampling technique, namely purposive sampling technique. The sample in this study were 10 students of the Islamic Guidance and Counseling Study Program, Faculty of Da'wah and Communication, UIN Raden Fatah Palembang. Data collection techniques in this study using interview techniques and observation techniques. In this study, the data were analyzed using qualitative descriptive analysis. The results obtained from this study are that the zuhud nature of students can be realized well where students are able not to feel happy about something they have and not feel sad if something is not owned; not feeling restless when insulted and not proud of being praised; and his heart is merely planted with fear, longing, and love for Allah SWT. So, it can be concluded that the zuhud nature of students can be realized by implementing hadith-based group guidance.
\end{abstract}

KEYWORDS: zuhud, group guidance, based hadist.

\section{PENDAHULUAN}

Kejernihan hati manusia merupakan hal yang sangat bernilai agar manusia dapat melakukan suatu tindakan dengan bijaksana. Kejernihan hati akan diperoleh manusia apabila ia menempatkan sesuatu yang tertinggi di dalam hatinya. Dalam hal ini, tidaklah sesuatu yang tertinggi itu melainkan kecintaan hamba terhadap Dzat yang telah menciptakannya. Selain itu, kejernihan hati juga akan didapatkan apabila manusia mampu menempatkan dunia pada tempat semestinya. Adapun tempat dunia pada manusia bukan pada hatinya dan juga dunia jangan dijadikan tujuan dalam menjalani kehidupan.

Pada hakikatnya, dunia adalah sementara. Manusia ibarat musafir yang hanya diberi kesempatan oleh Allah swt. untuk melintas sejenak agar memperoleh hikmah dari apa yang telah dirasakannya di dunia. Dari Ibnu Umar radhiallohu 'anhuma beliau berkata: Rasulullah saw. pernah memegang kedua pundakku seraya bersabda, "Jadilah engkau di dunia seperti orang asing atau musafir." Ibnu Umar berkata: "Jika engkau berada di sore hari jangan menunggu datangnya pagi dan jika engkau berada pada waktu pagi hari jangan menunggu datangnya sore. Pergunakanlah masa sehatmu sebelum sakit dan masa hidupmu sebelum mati." (HR. Bukhari). Dari hadits di atas 
dapat dipahami bahwa manusia hendaknya menjadi orang asing di dunia sehingga ia tidak melekat dan seakan-akan menjadi pemilik dari segala yang ia miliki di dunia. Dengan demikian, akan hadir kesadaran pada diri manusia bahwa ia sewaktu-waktu akan pergi meninggalkan dunia ini dan melanjutkan perjalanannya menuju akhirat yang kekal.

Akhirat adalah kampung halaman manusia, sebaik-baiknya tempat kembali. Sedangkan dunia adalah ladang untuk manusia untuk memperoleh bekal sebelum sampai ke akhirat. Allah swt. telah menjadikan buminya sebagai tempat untuk hambanya dalam mencapai keberhasilan atas ujian-ujian yang Allah swt. berikan. Allah swt. memberikan ujian bagi manusia di dunia agar Allah swt. mengetahui siapa yang benar-benar beriman dan bertaqwa kepadaNya. Siapa yang tetap beriman dan bertaqwa kepada Allah swt. maka la akan menghadiahkan surga yang keindahannya belum dapat terlukiskan dengan sebenar-sebenarnya lukisan surga. Adapun keadaan dari penduduk surga dijelaskan dalam hadist berikut: Rasulullah Saw. bersabda, 'Permulaan rombongan yang memasuki surga, gambaran mereka adalah menyerupai rembulan di malam purnama. Mereka tiada meludah di dalamnya, tiada beringus, tiada kotoran mata. Wadah dan sisir mereka terbuat dari emas dan perak, tiada pernah buang air besar atau kecil, peluh mereka misik, dan tiap-tiap dari mereka dua istri (bidadari) yang seolah tampak urat betis di balik kulit mereka karena cantiknya. Tiada perselisihan di antara mereka dan tiada saling membenci. Hati-hati mereka satu, senantiasa bertasbih kepada Allah di pagi dan sore hari.'” (HR. Ahmad dan HR. Muslim)

Janji Allah swt. kepada manusia adalah pasti. Allah swt. berfirman: "Dan sampaikanlah berita gembira kepada mereka yang beriman dan berbuat baik, bahwa bagi mereka disediakan surga-surga yang mengalir sungai-sungai di dalamnya. Setiap mereka diberi rezeki buah-buahan dalam surgasurga itu, mereka mengatakan: "Inilah yang pernah diberikan kepada kami dahulu". Mereka diberi buah-buahan yang serupa dan untuk mereka di dalamnya ada isteri-isteri yang suci dan mereka kekal di dalamnya." (QS. Al-Baqarah: 25) Jika meresapi firman Allah swt. tersebut dapat dipahami bahwa janjiNya kepada manusia sangat luar biasa. Kenikmatan di surga bukan bandingan dari kenikmatan dunia yang tidak ada apa-apanya. Dalam hal ini, manusia yang beruntung adalah manusia yang menggunakan akal pikirannya untuk dapat meresapi apa yang telah dijanjikan oleh Allah swt. Percaya dan yakin akan balasan dari setiap perbuatan adalah kunci yang utama untuk dapat berbenah diri dalam rangka meraih janjiNya tersebut.

Surga akan dapat diraih apabila manusia dapat membuktikan cintanya kepada Dzat Pencipta. Seseorang yang mencintai sesuatu biasanya akan melakukan hal-hal yang disukai oleh sesuatu tersebut. Manusia tidak dapat hanya berkata bahwa ia mencintai Allah swt. tanpa melakukan apaapa yang disukai Allah swt. Artinya, apabila manusia mencintai Allah swt., tentu ia akan mengikuti apa saja perintah yang dapat membuat Allah swt. cinta dengannya karena perbuatannya tersebut. Allah swt. menyuruh hambanya untuk melaksanakan sholat, zakat, puasa dan lainnya. Akan tetapi, hambanya tidak melakukannya atau mengabaikannya karena malas. Dengan demikian, kecintaannya kepada Allah swt. masih dipertanyakan. Karena jika ia cinta, ia takut sesuatu yang dicintainya akan marah apabila ia melakukan sesuatu yang tidak disukai oleh yang dicintainya. Adapun bukti kecintaaan manusia kepada Allah swt. yang telah menciptakannya dapat dirasakan dengan hadirnya sifat zuhud pada diri manusia tersebut.

Zuhud adalah tidak mencintai dunia dan tidak menempatkan dunia di dalam hati. Dengan demikian, manusia tidak berusaha secara berlebihan untuk mendapatkan dunia apa lagi dengan segala cara bahkan dengan cara yang tidak diridhoi Allah swt. Asal dari kata zuhud yakni "Zahada, Zuhda" yang bermakna meninggalkan dan tidak menyukai, sedangkan menurut istilah zuhud adalah 
meninggalkan kehidupan atau kesenangan duniawi dan milih akhirat. Dalam memahami pengertian tersebut, bukan berarti bahwa zuhud tersebut memutuskan diri dengan dunia dan tidak mau berhubugan apapun dengan dunia. Akan tetapi, zuhud adalah upaya mengosongkan hati dari kecintaan terhadap dunia dan menjauhikan diri dari rasa bangga jika memiliki segala yang ada di dunia ini. Hamka (2000) mengemukakan bahwa zuhud merupakan perasaan yang tidak mencintai kesenangan dan kemewahan dunia walaupun memiliki harta benda dunia.

Individu yang memiliki sifat zuhud adalah individu yang memiliki karakteristik sifat zuhud yang meliputi: (a) tidak merasa gembira terhadap sesuatu yang dimilikinya dan tidak pula merasa sedih jika sesuatu itu tidak dimilikinya (al-Ghazali dalam Hafiun, 2017); (b) tidak merasa resah apabila dihina dan tidak berbangga hati apabila dipuji (Alwi dalam Hafiun, 2017); dan (c) hatinya hanya semata-mata tertanam rasa takut, rindu, dan cinta kepada Allah swt (Hafiun, 2017). Dari karakteristik yang telah dijelaskan di atas, dapat dipahami bahwa sifat zuhud adalah jika suatu luput dari manusia, maka tidak ada rasa sedih pada dirinya karena ia tidak cinta secara berlebihan dengan sesuatu tersebut. Sebaliknya, apabila Allah swt. mengizinkannya untuk mendapatkan sesuatu, ia tidak merasa bahagia yang berlebihan seakan-akan dunia ini milikinya. Selain itu, orang dapat dikatakan memiliki sifat zuhud apabila ia tidak bangga atas pujian yang ia terima sehingga ia menjadi besar kepala dan juga ia tidak merasa sedih, resah, dan kecewa jika ada orang lain yang mengejeknya dan menghinanya. Yang terakhir, ciri orang yang zuhud adalah hanya Allah swt. yang menjadi tujuan hidupnya di mana ada rasa cinta, rindu dan takut yang mendalam kepada Dzat yang nanti akan ditemuinya untuk mempertanggungjawabkan segala perbuatannya selama ia hidup di dunia.

Sangat penting bagi seseorang agar dapat memiliki sifat zuhud di dalam dirinya. Dengan adanya sifat zuhud, maka ketamakan akan dunia akan dapat dihindari. Orang yang memiliki sifat zuhud akan mudah menghadirkan rasa syukur di dalam dirinya atas apa saja yang telah Allah swt. berikan kepadanya. Tentu, mengeluh bukan hal yang disukai oleh orang yang zuhud. Selain itu, dengan adanya sifat zuhud, manusia akan terhindar dari kesombongan. Sebab, orang yang mengosongkan hatinya dari dunia akan merasa ia bahwa dunia ini hanyalah sementara dan isinya adanya milik Allah swt. yang dititipkan kepada manusia. Kemudian, orang yang zuhud memiliki rasa takut kepada Allah swt, sehingga ia akan menggunakan akal pikirannya sebelum bertindak. la memikirkan apakah Allah swt. ridho terhadapnya dan terhadap apa yang ia perbuat di dunia.

Dengan zuhud, individu akan mencintai Allah swt. dengan tanpa hijab yang menutupinya dengan Allah swt. Sesuatu yang dapat memalingkan diri manusia terhadap Allah swt. dapat meliputi harta benda, orang yang dicintai seperti orang tua, anak, suami dan istri, serta sesuatu apapun yang dapat menjadikan Allah swt. tertutup dari mata hati manusia. Padahal manusia hendaknya mencintai Allah swt. dengan cinta yang tertinggi melebihi apapun. Hal tersebut dikarenakan, Allah swt. tidak menciptakan manusia kecuali untuk menyembahNya. Allah swt. berfirman: "Dan Aku tidak menciptakan jin dan manusia melainkan supaya mereka beribadah kepada-Ku." (QS. Adz Dzariyat: 56). Dengan demikian, penelitian mengenai sifat zuhud ini sangat diperlukan agar dapat menjadikan setiap manusia berada pada zuhudnya yang tertinggi.

Sifat zuhud telah diteliti oleh para peneliti sebelumnya. Salah satunya adalah penelitian yang dilakukan oleh Saripah dkk. (2017) mengenai "Fungsi zuhud terhadap ketenangan jiwa (Studi analisis terhadap tafsir Jailani Karya Abd al-Qadir Jailani). Hasil dari penelitian menemukan bahwa dalam beberapa ayat tentang zuhud terdapat kategorisasi tersendiri, yakni: (1) permisalan dunia pada 3 ayat, (2) sifat dan hakikat dunia 9 ayat, serta (3) kerugian memilih dunia 9 ayat. Penafsir 
mengungkapkan bahwa zuhud merupakan perilaku hidup yang tidak menyukai kehidupan dunia dan mengutamakan akhirat. Hal ini dikarenakan pengetahuan dan pemahamannya terhadap hakikat dunia. Sehingga mereka senantiasa menjalankan amal saleh yang mendekatkan hamba kepada Allah. Dengan demikian, Allah menganugerahkannya martabat tinggi, pahala dan ketenangan jiwa serta dijauhkan dari siksa. Ketika susah, hatinya tidak akan terguncang, sebab ia senantiasa ridho akan takdirnya. Oleh karena itu, orang yang zuhud akan senantiasa tenang jiwanya.

Selain itu, Maknin (2011) juga telah meneliti hal yang berkaitan dengan zuhud yakni ia meneliti mengenai "Konsep dan Implementasi Zuhud dalam Pemenuhan Kebutuhan Primer Santri (Studi pada beberapa Pesantren Tradisional dan Modern di Kabupaten Malang)." Adapun hasil penelitiannya menunjukkan bahwa implementasi zuhud sangat banyak ditemukan di pondok pesantren tradisional. Sementara itu, implementasi zuhud tidak ditemukan di pondok pesantren modern karena budaya modern dan gaya hidup. Di pesantren Islam modern, zuhud tetap menjadi kerangka kerja konseptual tanpa implementasi yang signifikan pada kehidupan siswa.

Dari hasil studi pendahuluan yang telah dilakukan oleh peneliti terhadap mahasiswa Program Studi Bimbingan dan Penyuluhan Islam Fakultas Dakwah dan Komunikasi UIN Raden Fatah Palembang menunjukkan bahwa masih ada beberapa mahasiswa yang sifat zuhud belum terwujud pada dirinya. Hal tersebut dapat terlihat dari masih seringnya mahasiswa merasa bahagia yang berlebihan saat mendapatkan sesuatu seperti mendapatkan IPK yang tinggi, sehingga mahasiswa menjadi terlalu berbangga hati. Selain itu, mahasiswa terkadang masih mengalami keresahan dan kesedihan apabila diejek oleh temannya karena tidak dapat menjawab pertanyaan saat diskusi di dalam kelas. Kemudian, mahasiswa juga masih dirundung kesedihan jika ia tidak mendapatkan harta seperti teman-temannya. Masih terdapat juga mahasiswa yang tidak takut akan hukuman dari Allah swt. jika melakukan suatu dosa seperti menyontek saat ujian dan masih suka menyinggung perasaan temantemannya.

Dari permasalahan yang diperoleh melalui studi pendahuluan, maka hendaknya ada upaya untuk mengatasinya sehingga terwujudnya sifat zuhud dari diri mahasiswa khususnya pada mahasiswa Program Studi Bimbingan dan Penyuluhan Islam Fakultas Dakwah dan Komunikasi UIN Raden Fatah Palembang. Bimbingan dan Konseling merupakan suatu upaya yang sangat penting untuk menerobos permasalahan mahasiswa seperti dalam rangka mewujudkan sifat zuhud tersebut. Layanan yang dapat dilakukan agar sifat zuhud mahasiswa dapat terbentuk adalah layanan bimbingan kelompok. Layanan bimbingan kelompok merupakan salah satu layanan bimbingan konseling yang dilaksanakan oleh konselor dengan memanfaatkan dinamika kelompok untuk membantu klien agar memperoleh pemahaman dalam rangka mengembangkan diri secara optimal. Bimbingan kelompok bertujuan untuk memberikan informasi dan masukan kepada anggota kelompok agar dapat mempermudah pengambilan keputusan dalam berperilaku (Ana dkk., 2017; Zhila \& Indri, 2019). Dalam penelitian ini, bimbingan kelompok yang dilakukan adalah untuk mewujudkan sifat zuhud pada diri klien yakni mahasiswa Bimbingan dan Penyuluhan Islam Fakultas Dakwah dan Komunikasi UIN Raden Fatah Palembang.

Penelitian terdahulu mengenai bimbingan kelompok telah dilakukan, misalnya penelitian yang dilakukan oleh Alamri (2015) mengenai layanan bimbingan kelompok dengan teknik self management untuk mengurangi perilaku terlambat masuk sekolah (Studi pada siswa kelas X SMA 1 Gebog tahun 2014/2015). Hasil penelitian menunjukkan bahwa pada pra siklus skor rata-rata adalah 41 menurun pada siklus I menjadi 28,63 dengan kategori cukup, dan pada siklus II menjadi 13,13 atau sangat 
rendah dengan kategori sangat baik. Ada penurunan dari siklus I ke siklus II yaitu sebesar 15,5 atau secara keseluruhan 27,88. Sehingga hipotesis tindakan dapat diterima, karena ada peningkatan dari indikator keberhasilan.

Selain itu, terdapat juga penelitian yang dilakukan oleh Ridhani dan Sutoyo (2016: 55) mengenai "Pengembangan model bimbingan kelonpok berbasis Islam untuk meningkatkan perilaku etik berkomunikasi siswa MTs Kota Banjarmasin." Penelitian ini menunjukkan hasil bahwa terbentuknya suatu model bimbingan kelompok berbasis Islam untuk meningkatkan perilaku etik berkomunikasi siswa MTs Kota Banjarmasin terhadap orang tua yang terdiri atas (1) rasional, (2) pengertian, (3) visi dan misi, (4) prinsip, (5) tujuan, (6) isi, (7) dukungan sistem, (8) tahapan, (9) evaluasi dan tindak lanjut, (10) materi layanan, serta (11) panduan pelaksanaan. Selain itu, terdapat hasil uji keefektifan model dengan uji-t independent berbantuan SPSS 16 diperoleh data T hitung $(10,603)>$ T tabel $(2,145)$ maka Ho ditolak dan Ha diterima sehingga dapat disimpulkan bahwa layanan bimbingan kelompok berbasis Islam efektif untuk meningkatkan etika berkomunikasi siswa terhadap orang tua.

Penelitian-penelitian yang telah dijelaskan di atas berfokus pad bimbingan kelompok dengan teknik self management dan bimbingan kelompok berbasis Islam. Adapun dalam penelitian ini fokusnya adalah bimbingan kelompok yang dilakukan dengan berbasis hadits. Adapun hadist merupakan sumber dari ajaran agama Islam yang kedua setelah kitab suci Al-qur'an. Dengan adanya hadits, maka dapat membantu memperjelas hukum-hukum yang ada di Al-qur'an. Al Thahhan (Tasbih, 2011) menjelaskan bahwa hadits adalah perkataan, perbuatan dan persetujuan, serta sifat yang disandarkan (udhifa) kepada Nabi saw. Dalam hal ini, manusia hendaknya mematuhi hukum kedua setelah Al-qur'an ini sehingga dapat menjalani hidup dengan benar untuk mencapai keridhaan Allah swt. Hadits memuat berbagai hukum islam misalnya mengenai zuhud di mana Rasulullah saw. telah memberikan perintah dan memberikan teladan kehidupan agar manusia dapat memperoleh sifat zuhud yang terbaik. Dengan demikian, peneliti berupaya meneliti mengenai bimbingan kelompok dengan menggunakan basis hadits.

\section{METODE}

Metode yang digunakan dalam penelitian ini adalah metode penelitian kualitatif. Menurut Lincoln dan Guba (Mulyadi, 2011) dalam penelitian kualitatif, peneliti hendaknya memanfaatkan diri sebagai instrumen, karena instrumen nonmanusia sulit digunakan secara luwe untuk menangkap berbagai realitas dari interaksi yang terjadi. Adapun penelitian ini bertujuan untuk mengetahui bagaimana mewujudkan sifat zuhud pada mahasiswa melalui bimbingan kelompok berbasis hadits. Sampel yang dipilih pada penelitian ini adalah mahasiswa Program Studi Bimbingan dan Penyuluhan Islam Fakultas Dakwah dan Komunikasi UIN Raden Fatah Palembang. Jumlah sampel yakni 10 orang mahasiswa yang diambil dengan salah satu teknik pengambilan sampel yaitu teknik purposive sampling. Teknik ini adalah teknik pengambilan sampel dengan menentukan kriteria-kriteria tertentu (Mukhsin dkk, 2017).

Dalam penelitian ini, teknik pengumpulan data yang dipilih adalah teknik wawancara dan observasi. Wawancara merupakan teknik pengumpulan data dengan cara tanya jawab lisan yang dilakukan secara sistematis guna mencapai tujuan penelitian (Sutoyo, 2014). Sedangkan observasi adalah pengamatan yang dilakukan secara langsung maupun tidak langsung terhadap objek yang sedang diteliti (Sutoyo, 2014). Dalam hal ini, kedua teknik pengumpulan data dapat saling melengkapi 
guna mendapatkan hasil penelitian yang tepat. Sedangkan untuk menganalisis data, peneliti memilih teknik analisis data deskriptif kualitatif. Analisis deskriptif kualitatif adalah metode pengolahan data dengan cara menganalisa faktor- faktor yang berkaitan dengan objek penelitian dengan penyajian data secara lebih mendalam terhadap objek penelitian (Prabowo \& Heriyanto, 2013).

\section{HASIL DAN PEMBAHASAN}

Dari hasil wawancara dan observasi mengenai penelitian tentang mewujudkan sifat zuhud pada mahasiswa melalui bimbingan kelompok berbasis hadits Rasulullah saw. ini, didapatkan hasil penelitian yakni (a) pelaksanaan bimbingan kelompok berbasis hadits untuk mewujudkan sifat zuhud mahasiswa dan (b) gambaran sifat zuhud mahasiswa setelah dilakukan bimbingan kelompok berbasis hadits.

\section{(a) Pelaksanaan bimbingan kelompok berbasis hadits untuk mewujudkan sifat zuhud mahasiswa.}

Pelaksanaan bimbingan kelompok berbasis hadits dilakukan oleh peneliti kepada 10 orang mahasiswa. Tahapan layanan bimbingan kelompok berbasis hadits dilalui dengan empat tahap. Adapun tahapan tersebut meliputi tahap pembentukan, tahap peralihan, tahap kegiatan serta tahap pengakhiran. Pelaksaaan bimbingan kelompok berbasis hadits secara keseluruhan berjalan dengan lancar walaupun ada beberapa hambatan seperti penentuan waktu kegiatan dan tempat kegiatan. Layanan bimbingan kelompok berbasis hadits akan diuraikan lebih jelas seperti berikut ini:

1) Tahap pembentukan

Pada tahap pembentukan, peneliti mencoba untuk membangun hubungan yang baik dengan anggota kelompok. Dengan demikian, akan tercipta keakraban dan kehangatan di dalam kelompok. Pada tahap ini, peneliti membuka kegiatan dengan mengucapkan salam, menanyakan kabar mahasiswa hari ini, serta melakukan kegiatan doa bersama yakni doa untuk membuka majelis ilmu. Peneliti sebagai pemimpin kelompok juga mengajak setiap anggota kelompok untuk melakukan perkenalan diri agar dapat menjalin tali silaturahim lebih dekat lagi. Pemimpin kelompok juga memberikan penjelasan mengenai konsep dasar dari kegiatan bimbingan kelompok berbasis hadits, lalu melaksanakan permainan-permainan untuk menyemarakan suasana yang mungkin kaku, serta yang terakhir pemimpin kelompok dan anggota kelompok bersiap untuk melanjutkan ke tahap selanjutnya yakni tahap peralihan.

2) Tahap peralihan

Tahap ini merupakan tahap yang penting agar tahap inti dari bimbingan kelompok berbasis hadits yakni tahap kegiatan dapat berjalan dengan baik. Dalam tahap ini, pemimpin kelompok berusaha menarik minat anggota kelompok sehingga dapat meningkatkan partisipasi mereka. Kemudian, peneliti sebagai pemimpin kelompok juga mencoba untuk meningkatkan keakraban dan mengajak anggota kelompok untuk memahami suasana yang terjadi sekarang serta yang terakhir menjelaskan dan mempersiapkan diri untuk melanjutkan ke tahap kegiatan.

3) Tahap kegiatan

Dalam tahap kegiatan, peneliti mulai memasuki kegiatan memberikan penjelasan dan melakukan diskusi mengenai sifat zuhud. Dalam hal ini, pemimpin kelompok menjelaskan topik yang akan dibahas yakni tentang "Sifat Zuhud". Adapun dalam penjelasannya tersebut, pemimpin kelompok juga menjelaskan hadits-hadist dari Rasulullah saw. yang berkaitan dengan materi yang dibahas. Kemudian, melaksanakan diskusi tanya jawab untuk materi- 
materi yang belum dipahami sehingga tujuan dari bimbingan kelompok berbasis hadits dapat tercapai.

4) Tahap pengakhiran

Pada tahap ini, pemimpin kelompok mengemukakan kepada anggota kelompok bahwa mereka telah sampai pada tahap akhir. Selanjutnya, hasil diskusi mengenai sifat zuhud disimpulkan oleh anggota kelompok. Kemudian, anggota kelompok juga mengungkapkan apa saja harapan, pesan serta kesan mereka setelah mengikuti kegiatan ini. Anggota kelompok juga membahas tentang kegiatan untuk pertemuan berikutnya. Pemimpin kelompok melakukan evaluasi, mengucapkan banyak terima kasih kepada anggota kelompok serta mengakhiri kegiatan dengan salam dan berjabat tangan.

Dalam pelaksanaan bimbingan kelompok berbasis hadits, pemimpin kelompok menjelaskan beberapa hadits yang berkaitan dengan sifat zuhud agar mahasiswa dapat tertarik dan termotivasi untuk mewujudkan sifat zuhud dalam diri masing-masing mahasiswa. Adapun hadits-hadits tersebut meliputi:

1) Tidak merasa gembira terhadap sesuatu yang dimilikinya dan tidak pula merasa sedih jika sesuatu itu tidak dimilikinya

a) 'Abbas Sahl bin Sa'ad Assa'idy ra bercerita: "Telah datang kepada Rasulullah seorang lakilaki dan berkata: "Wahai Rasulullah, tunjukkanlah kepadaku suatu amal yang apabila aku mengamalkannya, aku dicintai oleh Allah dan oleh manusia." Rasulullah menjawab: "Zuhudlah engkau terhadap dunia, niscaya Allah mencintaimu. Dan zuhudlah engkau terhadap apa yang dimiliki orang, niscaya mereka akan mencintaimu." (HR. Ibnu Majah)

b) Ahmad ibn Syabib ibn Sa'id menceritakan kepada kami, Ayahku menceritakan kepada kami dari Yunus, Ibn Syihab berkata: Abdullah ibn Abdullah ibn Atbah menceritakan kepadaku, ia berkata: Abu Abu Hurairah ra. Berkata: Rasulullah saw bersabda: "Andaikan aku mempunyai emas sebesar bukit Uhud, aku pasti lebih senang kalau emas itu tidak menginap di tempatku sampai tiga malam dan masih tersisa di tempatku, kecuali sesuatu yang aku persiapkan untuk membayar hutang." (Wahid, 2016)

c) Qutaibah ibn Sa'id dan Abu Bakar ibn Abu Syaibah berkata: Abu alAhwas menceritakan kepada kami dari Simak ia berkata: Aku telah mendengar al-Nu'man ibn Basyir: Ketika Umar ibn Khattab melihat bahwa orang-orang sangat mementingkan urusan dunia, ia berkata: "Sungguh saya melihat Rasulullah saw. kadang-kadang sehari penuh tidak mendapatkan makanan walaupun hanya kurma yang paling buruk untuk mengisi perutnya. (Wahid, 2016)

2) Tidak merasa resah apabila dihina dan tidak berbangga hati apabila dipuji

a) Zuhair ibn Harb menceritakan kepadaku, Jarir menceritakan kepada kami, Abu Mua'wiyah dan Waki menceritakan kepada kami dari al A'masy dari Abu Shalih dari Abu Hurairah ia berkata: Rasulullah saw. Bersabda: Perhatikanlah orang yang berada di bawahmu dan janganlah kamu memperhatikan orang yang berada di atasmu, karena yang demikian itu lebih pantas, agar kamu semua tidak menganggap remeh rahmat Allah yang telah dikaruniakan kepadamu. (Wahid, 2016)

b) Dari Abu Jafar, ia berkata: Aku mendengar Abu Hurairah berkata: Rasulullah Saw bersabda: "Tiga doa yang tidak diragukan lagi kemustajabannya: (1) doa orang yang terzalimi, (2) doa orang yang bepergian, (3) doa orang tua untuk ana knya." (HR. Ahmad)

c) Dari al-Zuhri. ia berkata: Rasulullah saw. Ditanya tentang zuhud di dunia, maka beliau menjawab: zuhud adalah "hendaknya mensyukuri rezeki yang halal dan menjauhkan diri dengan penuh kesabaran dari sesuatu yang haram." (Wahid, 2016) 
d) Abdullah ibn Abdurrahman menceritakan kepada kami, Muhammad ibn Mubarak menceritakan kepada kami, Amr ibn Waqid menceritakan kepada kami, Yunus ibn Halbas dari Abu Idris al-Khaulany dari Abu Dzar dari Nabi saw. Bersabda: Zuhud di dunia bukan berarti mengharamkan yang halal, bukan juga menghilangkan harta, akan tetapi zuhud di dunia adalah hendaknya janganlah engkau lebih meyakini apa yang engkau miliki daripada yang dimiliki Allah, dan hendaklah ketika tertimpa musibah menerima dengan senang walaupun memberikan kesan yang memberatkan dirimu." (Wahid, 2016)

3) Hatinya hanya semata-mata tertanam rasa takut, rindu, dan cinta kepada Allah swt.

a) "Dari Abu Hurairah RA, Rasulullah bersabda bahwa Allah berfirman, 'Siapa yang memusuhi wali-Ku, maka Aku mengumumkan perang kepadanya. Tiada hamba-Ku yang mendekatkan diri kepada-Ku dengan suatu (amalan) melebihi dari apa yang Kuwajibkan kepadanya. Hamba-Ku senantiasa mendekat kepada-Ku dengan amalan sunnah sehingga Aku mencintai-Nya. Bila Aku mencintainya, maka Aku menjadi telinga sebagai alat pendengarannya, menjadi mata sebagai alat penglihatannya, menjadi tangan sebagai alat pemegang, dan menjadi kaki sebagai alatnya berjalan. Jika ia meminta sesuatu kepada-Ku, niscaya Aku memberinya. Jika ia meminta perlindungan kepada-Ku, niscaya Aku melindunginya. Tiada 'kebimbangan' sesuatu yang Kulakukan selain mencabut nyawa orang beriman yang mana ia tidak menyukai kematian dan Aku tidak suka menyakitinya," (HR. Bukhari)

b) Dari Anas bin Malik radhiallahu 'anhu bahwa Rasulullah shallallahu 'alaihi wa sallam bersabda, "Ada tiga sifat, barangsiapa yang memilikinya maka dia akan merasakan manisnya iman (kesempurnaan iman): menjadikan Allah dan rasul-Nya lebih dicintai daripada (siapapun) selain keduanya, mencintai orang lain semata-mata karena Allah, dan merasa benci (enggan) untuk kembali kepada kekafiran setelah diselamatkan oleh Allah sebagaimana enggan untuk dilemparkan ke dalam api" (HR. Bukhori dan Muslim)

c) Nabi shallallahu 'alaihi wa sallam bersabda: "Barang siapa yang suka berjumpa dengan Allah maka Allah suka berjumpa dengannya, dan barang siapa yang benci bertemu dengan Allah maka Allah benci untuk bertemu dengannya" (HR. Muslim)

d) Dari Anas radhiallahu 'anhu, katanya: "Rasulullah shalallahu alaihi wasalam berkhutbah, tidak pernah saya mendengar suatu khutbah pun yang semacam itu- karena amat menakutkan. Beliau shalallahu alaihi wasalam bersabda: "Andaikata engkau semua dapat mengetahui apa yang saya ketahui, niscaya engkau semua akan ketawa sedikit dan menangis banyak-banyak." Anas berkata: "Maka para sahabat Rasulullah shalallahu alaihi wasalam sama menutupi mukanya sendiri-sendiri dan mereka itu menangis terisakisak." (Muttafaq 'alaih)

\section{(b) Gambaran sifat zuhud mahasiswa setelah dilakukan bimbingan kelompok berbasis hadits}

Sebelum dilaksanakan bimbingan kelompok berbasis hadits, subjek penelitian yakni mahasiswa Program Studi Bimbingan dan Penyuluhan Islam Fakultas Dakwah dan Komunikasi UIN Raden Fatah Palembang belum mewujudkan sifat zuhud yang baik ke dalam kehidupan sehariharinya. Dengan dilaksanakannya bimbingan kelompok berbasis hadits, sifat zuhud dapat terwujud pada diri mahasiswa tersebut. Hal tersebut diperoleh peneliti dari hasil wawancara dan observasi kepada mahasiswa. Adapun hasil observasi dan wawancara mengenai gambaran perwujudan sifat zuhud terdiri dari tiga aspek yakni sebagai berikut: 
Tabel 1. Hasil observasi mengenai gambaran sifat zuhud mahasiswa setelah dilakukan bimbingan kelompok berbasis hadits

\begin{tabular}{|c|c|c|c|c|}
\hline \multirow[t]{2}{*}{ No. } & \multirow[t]{2}{*}{ Aspek } & \multirow[t]{2}{*}{ Indikator } & \multicolumn{2}{|c|}{$\begin{array}{l}\text { Jumlah } \\
\text { Responden }\end{array}$} \\
\hline & & & Ya & Tidak \\
\hline \multirow[t]{5}{*}{1.} & $\begin{array}{l}\text { Tidak merasa gembira } \\
\text { terhadap sesuatu yang }\end{array}$ & $\begin{array}{l}\text { a. Merasa biasa saja ketika } \\
\text { memiliki sesuatu }\end{array}$ & 9 & 1 \\
\hline & $\begin{array}{l}\text { dimilikinya dan tidak } \\
\text { pula merasa sedih jika }\end{array}$ & $\begin{array}{l}\text { b. Tidak terlalu senang dengan } \\
\text { sesuatu yang dimiliki }\end{array}$ & 9 & 1 \\
\hline & $\begin{array}{l}\text { sesuatu itu tidak } \\
\text { dimilikinya }\end{array}$ & $\begin{array}{l}\text { c. Merasa biasa saja jika ada } \\
\text { sesuatu yang hilang darinya }\end{array}$ & 8 & 2 \\
\hline & & $\begin{array}{l}\text { d. Tidak terlalu bersedih hati } \\
\text { apabila kehilangan sesuatu } \\
\text { tersebut }\end{array}$ & 8 & 2 \\
\hline & \multicolumn{2}{|r|}{ Rata-rata } & 8,5 & 1,5 \\
\hline \multirow[t]{5}{*}{2.} & \multirow{5}{*}{$\begin{array}{l}\text { Tidak merasa resah } \\
\text { apabila dihina dan } \\
\text { tidak berbangga hati } \\
\text { apabila dipuji }\end{array}$} & $\begin{array}{l}\text { a. Tetap tenang jika ada orang } \\
\text { yang menghinanya }\end{array}$ & 8 & 2 \\
\hline & & $\begin{array}{l}\text { b. Tidak merasa resah apabila } \\
\text { ada penghinaan dari orang } \\
\text { lain }\end{array}$ & 8 & 2 \\
\hline & & $\begin{array}{l}\text { c. Berhati-hati dengan pujian } \\
\text { dari orang lain }\end{array}$ & 9 & 1 \\
\hline & & $\begin{array}{l}\text { d. Tidak berbangga hati jika } \\
\text { dipuji oleh orang lain }\end{array}$ & 9 & 1 \\
\hline & & ata-rata & 8,5 & 1,5 \\
\hline \multirow[t]{4}{*}{3.} & \multirow{4}{*}{$\begin{array}{l}\text { Hatinya hanya semata- } \\
\text { mata tertanam rasa } \\
\text { takut, rindu, dan cinta } \\
\text { kepada Allah swt. }\end{array}$} & $\begin{array}{l}\text { a. Adanya rasa takut di dalam } \\
\text { hati hanya kepada Allah } \\
\text { swt. }\end{array}$ & 8 & 2 \\
\hline & & $\begin{array}{l}\text { b. Adanya rasa rindu yang } \\
\text { mendalam di dalam hati } \\
\text { hanya kepada Allah swt. }\end{array}$ & 8 & 2 \\
\hline & & $\begin{array}{l}\text { c. Adanya rasa cinta yang } \\
\text { mendalam di dalam hati } \\
\text { hanya kepada Allah swt. }\end{array}$ & 8 & 2 \\
\hline & & ata-rata & 8 & 2 \\
\hline
\end{tabular}

Dari tabel di atas dijelaskan bahwa hasil observasi mengenai gambaran sifat zuhud mahasiswa setelah dilakukan bimbingan kelompok berbasis hadits pada aspek "Tidak merasa gembira terhadap sesuatu yang dimilikinya dan tidak pula merasa sedih jika sesuatu itu tidak dimilikinya" diperoleh rata-rata yang berada pada kategori "Ya" yakni sebesar 8,5 dan yang berada pada kategori "Tidak" adalah sebesar 1,5. Adapun pada aspek "Tidak merasa resah apabila dihina dan tidak berbangga hati apabila dipuji" diperoleh rata-rata sebesar 8,5 yang berada pada kategori "Ya, sedangkan pada kategori "Tidak" rata-ratanya adalah 1,5. Selanjutnya, pada aspek "Hatinya hanya semata-mata tertanam rasa takut, rindu, dan cinta kepada Allah swt." diperoleh rata-rata yang berada pada kategori "Ya" yakni 
sebesar 8 dan yang berada pada kategori "Tidak" adalah sebesar 2. Jadi, dapat disimpulkan bahwa telah terwujudnya sifat zuhud mahasiswa setelah dilakukan bimbingan kelompok berbasis hadits.

Tabel 2. Hasil wawancara mengenai gambaran sifat zuhud mahasiswa setelah dilakukan bimbingan kelompok berbasis hadits

\begin{tabular}{|c|c|c|c|c|}
\hline \multirow[b]{2}{*}{ No. } & \multirow[b]{2}{*}{ Aspek } & \multirow[b]{2}{*}{ Indikator } & \multicolumn{2}{|c|}{ Jumlah Responden } \\
\hline & & & $\begin{array}{l}\text { Yang } \\
\text { menjawab } \\
\text { "Ya" }\end{array}$ & $\begin{array}{l}\text { Yang } \\
\text { menjawab } \\
\text { "Tidak" }\end{array}$ \\
\hline \multirow[t]{5}{*}{1.} & $\begin{array}{l}\text { Tidak merasa } \\
\text { gembira }\end{array}$ & $\begin{array}{l}\text { a. Merasa biasa saja ketika } \\
\text { memiliki sesuatu }\end{array}$ & 10 & 0 \\
\hline & $\begin{array}{l}\text { terhadap } \\
\text { sesuatu yang }\end{array}$ & $\begin{array}{l}\text { b. Tidak terlalu senang dengan } \\
\text { sesuatu yang dimiliki }\end{array}$ & 9 & 1 \\
\hline & $\begin{array}{ll}\text { dimilikinya } & \text { dan } \\
\text { tidak } & \text { pula }\end{array}$ & $\begin{array}{l}\text { c. Merasa biasa saja jika ada } \\
\text { sesuatu yang hilang darinya }\end{array}$ & 8 & 2 \\
\hline & $\begin{array}{l}\text { merasa sedih } \\
\text { jika sesuatu itu } \\
\text { tidak dimilikinya }\end{array}$ & $\begin{array}{l}\text { d. Tidak terlalu bersedih hati } \\
\text { apabila kehilangan sesuatu } \\
\text { tersebut }\end{array}$ & 10 & 0 \\
\hline & & Rata-rata & 9,25 & 0,75 \\
\hline \multirow[t]{5}{*}{2.} & $\begin{array}{ll}\text { Tidak } & \text { merasa } \\
\text { resah } & \text { apabila }\end{array}$ & $\begin{array}{l}\text { a. Tetap tenang jika ada orang } \\
\text { yang menghinanya }\end{array}$ & 8 & 2 \\
\hline & $\begin{array}{l}\text { dihina dan tidak } \\
\text { berbangga hati } \\
\text { apabila dipuji }\end{array}$ & $\begin{array}{l}\text { b. Tidak merasa resah apabila } \\
\text { ada penghinaan dari orang } \\
\text { lain }\end{array}$ & 8 & 2 \\
\hline & & $\begin{array}{l}\text { c. Berhati-hati dengan pujian } \\
\text { dari orang lain }\end{array}$ & 10 & 0 \\
\hline & & $\begin{array}{l}\text { d. Tidak berbangga hati jika } \\
\text { dipuji oleh orang lain }\end{array}$ & 10 & 0 \\
\hline & & Rata-rata & 9 & 1 \\
\hline \multirow[t]{4}{*}{3.} & $\begin{array}{l}\text { Hatinya hanya } \\
\text { semata-mata } \\
\text { tertanam rasa }\end{array}$ & $\begin{array}{l}\text { a. Adanya rasa takut di dalam } \\
\text { hati hanya kepada Allah } \\
\text { swt. }\end{array}$ & 9 & 1 \\
\hline & $\begin{array}{l}\text { takut, rindu, dan } \\
\text { cinta kepada } \\
\text { Allah swt. }\end{array}$ & $\begin{array}{l}\text { b. Adanya rasa rindu yang } \\
\text { mendalam di dalam hati } \\
\text { hanya kepada Allah swt. }\end{array}$ & 10 & 0 \\
\hline & & $\begin{array}{l}\text { c. Adanya rasa cinta yang } \\
\text { mendalam di dalam hati } \\
\text { hanya kepada Allah swt. }\end{array}$ & 10 & 0 \\
\hline & & Rata-rata & 9,67 & 0,33 \\
\hline
\end{tabular}

Berdasarkan hasil wawancara tentang gambaran sifat zuhud mahasiswa setelah dilakukan bimbingan kelompok berbasis hadits pada aspek "Tidak merasa gembira terhadap sesuatu yang dimilikinya dan tidak pula merasa sedih jika sesuatu itu tidak dimilikinya" diperoleh rata-rata yang menjawab"Ya" yakni sebesar 9,25 dan yang menjawab"Tidak" adalah sebesar 0,75. Adapun pada aspek "Tidak merasa resah apabila dihina dan tidak berbangga hati apabila dipuji" diperoleh rata-rata sebesar 9 yang menjawab"Ya, sedangkan yang menjawab "Tidak" rata-ratanya adalah 1. Selanjutnya, 
pada aspek "Hatinya hanya semata-mata tertanam rasa takut, rindu, dan cinta kepada Allah swt." diperoleh rata-rata yang menjawab "Ya" yakni sebesar 9,67 dan yang menjawab "Tidak" adalah sebesar 0,33. Jadi, dapat disimpulkan bahwa telah terwujudnya sifat zuhud mahasiswa setelah dilakukan bimbingan kelompok berbasis hadits.

Adapun perwujudan sifat zuhud pada mahasiswa Program Studi Bimbingan dan Penyuluhan Islam Fakultas Dakwah dan Komunikasi UIN Raden Fatah Palembang setelah diterapkan bimbingan kelompok berbasis hadits pada setiap aspek akan dirincikan sebagai berikut:

1) Tidak merasa gembira terhadap sesuatu yang dimilikinya dan tidak pula merasa sedih jika sesuatu itu tidak dimilikinya

Sifat zuhud sudah terbentuk pada mahasiswa salah satunya pada aspek "tidak merasa gembira terhadap sesuatu yang dimilikinya dan tidak pula merasa sedih jika sesuatu itu tidak dimilikinya". Dalam hal ini, mahasiswa tampak telah dapat mengontrol perasaannya terhadap sesuatu hal yang bersifat duniawi dengan mengingat akhirat sebagai hal yang utama. Hal tersebut dapat dilihat dari mahasiswa yang merasa biasa saja dan tidak merasa gembira terhadap apa saja yang dititipkan Allah swt. kepadanya. Misalnya, ketika mahasiswa memperoleh IPK yang sangat memuaskan, ia tidak terlalu gembira dengan hal tersebut melainkan lebih merasa bersyukur kepada Allah swt. atas hasil yang didapatkannya tersebut adalah berkat izin Allah swt. Selain itu, saat telah mendapatkan nikmat harta yang cukup seperti uang kos, uang jajan bulanan, dan uang UKT yang cukup bahkan berlebih, mahasiswa juga tidak merasa bergembira yang berlebihan. Bahkan hal tersebut digunakannya untuk membantu temannya yang kesulitan.

Mahasiswa juga merasa biasa saja dan tidak merasa sedih apabila sesuatu tidak dimilikinya. Misalnya, mahasiswa tidak merasa kecewa dan bersedih hati saat teman-teman kuliahnya sering berganti pakaian baru, sedangkan ia hanya memakai pakaian yang itu-itu saja saat kuliah maupun saat berpergian ke tempat lain. Selain itu, mahasiswa tidak dirundung kesedihan apabila ia tidak memiliki keluarga yang lengkap seperti teman-temannya. la menganggap bahwa itu adalah ujian dari Allah swt. kepadanya dengan tujuan agar ia belajar untuk terus bersabar untuk mendapatkan surga yang terindah. Mahasiswa juga tidak bersedih hati apabila usahanya dalam belajar tidak memperoleh hasil yang baik. la bahkan terus belajar agar dapat memahami pelajaran mata kuliah dengan lebih baik lagi.

2) Tidak merasa resah apabila dihina dan tidak berbangga hati apabila dipuji

Aspek "tidak merasa resah apabila dihina dan tidak berbangga hati apabila dipuji" pada mahasiswa juga telah terwujud melalui layanan bimbingan kelompok berbasis hadits. Dalam hal ini, mahasiswa telah mampu untuk tetap tenang dan tidak merasa resah jika ada orang lain yang menghinanya. Apabila ada temannya yang mengejeknya di kelas karena ia pergi ke kampus dengan berjalan kaki, maka ia tidak langsung marah dan bersedih hati atas ejekannya tersebut. Ia yakin bahwa Allah swt. akan membalas semua perbuatan zolim dari temannya tersebut. Selain itu, jika ada teman yang mengejeknya dalam hal lain seperti karena tidak dapat mengerjakan soal, IPK kecil, dan belum dapat membeli buku kuliah, maka mahasiswa tersebut tidak merasa minder dan berkecil hati.

Adapun mahasiswa juga telah mampu berhati-hati dengan pujian yang dilontarkan oleh orang lan serta tidak terlalu berbangga hati apabila ia mendapatkan pujian dari orang lain. Seperti bilamana mahasiswa tersebut mendapatkan IPK yang tertinggi, maka mahasiswa 
tersebut tidak berbangga hati dan tidak berperilaku sombong kepada teman-temannya yang kemampuan akademik di bawah peringkatnya. Selain itu, apabila ada subjek penelitian yang melalui izin Allah swt. mendapatkan harta kekayaan yang lebih sehingga ia dapat membeli motor untuk pergi kuliah, dapat membelli buku serta membayar keperluan kuliah, maka mahasiswa tersebut tidak menyombongkan dirinya. Bahkan, ada upaya untuk membantu orang lain yang mengalami kekurangan harta.

3) Hatinya hanya semata-mata tertanam rasa takut, rindu, dan cinta kepada Allah swt.

Pada aspek "hatinya hanya semata-mata tertanam rasa takut, rindu, dan cinta kepada Allah swt." telah terwujud pada diri mahasiswa. Hal tersebut dapat terlihat dari peningkatan ibadah dari mahasiswa, seperti pada ibadah sholat, puasa, sedekah, pergi ke masjid, menghadiri majelis ilmu, membantu orang lain dalam hal kebaikan, dan lainnya. Hal tersebut merupakan bukti rasa cinta, rindu sekaligus takut kepada Allah swt. Selain itu, mahasiswa juga telah menjauhi perbuatan dosa yang dapat menjerumuskannya ke dalam neraka. Hal tersebut tampak dari mahasiswa yang telah menjunjung tinggi kejujuran sehingga mereka ketika UAS tidak mencontek, tidak mengejek teman-teman yang memiliki kekurangan, tidak meninggalkan kewajiban untuk membayar ketika membeli makanan di kantin, dan lain sebagainya.

Dari hasil penelitian tersebut dapat dikatakan bahwa layanan bimbingan kelompok berbasis hadits dapat menjadi suatu solusi untuk dapat mewujudkan sifat zuhud mahasiswa. Hasil penelitian di atas sejalan dengan hasil penelitian yang diteliti oleh Irawan (2013) mengenai "Efektivitas Teknik Bimbingan Kelompok untuk Meningkatkan Konsep Diri Remaja (Studi Pre-Eksperimen Pada Siswa Kelas X SMK Yapema Gadingrejo Lampung). Adapun hasil penelitiannya meliputi adanya peningkatan konsep diri dengan menggunakan teknik bimbingan konseling kelompok, hal ini dibuktikan dengan terjadinya perubahan yang signifikan pada diri siswa yang memiliki konsep diri negatif atau rendah mengarah pada perubahan konsep diri positif.

Selain itu penelitian yang dilakukan oleh Sumantri dkk. (2017) yang berjudul "Role Play dalam Layanan Bimbingan Kelompok untuk Membina Self-Efficacy Siswa." Pengujian hipotesis dalam penelitian ini menunjukan angka probabilitas Asymp.Sig. (2-tailed) self-efficacy siswa sebesar 0,000 atau probabilitas di bawah alpha 0,05 $(0,000<0,05)$ dari hasil tersebut $\mathrm{HO}$ diterima $\mathrm{H} 1$ ditolak. Hasil penelitian tersebut menunjukan bahwa layanan bimbingan kelompok melalui role-play efektif untuk membina self-efficacy siswa di sekolah menengah kejuruan (SMK) Budhi Warman II Jakarta Timur.

Dari beberapa penelitian di atas dapat dikatakan bahwa layanan bimbingan kelompok merupakan layanan yang dapat dimanfaatkan konselor untuk klien dalam membantu mengembangkan diri secara optimal baik pada bidang sosial, pribadi, belajar, karier, serta keagamaan. Dari hasil penelitian ini serta hasil penelitian terdahulu dapat dikatakan bahwa tujuan penelitian ini yang berupa "untuk mengetahui bagaimana mewujudkan sifat zuhud pada mahasiswa melalui bimbingan kelompok berbasis hadits" dapat tercapai.

\section{KESIMPULAN}

Berdasarkan hasil dari penelitian, dapat disimpulkan bahwa layanan bimbingan kelompok berbasis hadits dapat menjadi suatu solusi dalam mewujudkan sifat zuhud pada mahasiswa Program Studi Bimbingan dan Penyuluhan Islam Fakultas Dakwah dan Komunikasi UIN Raden Fatah Palembang. Hal tersebut dapat dilihat dari mahasiswa yang (a) tidak merasa gembira terhadap 
sesuatu yang dimilikinya dan tidak pula merasa sedih jika sesuatu itu tidak dimilikinya, (b) tidak merasa resah apabila dihina dan tidak berbangga hati apabila dipuji, dan (c) hatinya hanya sematamata tertanam rasa takut, rindu, dan cinta kepada Allah swt.

\section{DAFTAR PUSTAKA}

Alamri, N. (2015). Layanan Bimbingan Kelompok Dengan Teknik Self Management Untuk Mengurangi Perilaku Terlambat Masuk Sekolah (Studi Pada Siswa Kelas X SMA 1 Gebog Tahun 2014/2015). Jurnal Konseling GUSJIGANG, 1(1).

Ana, A., Wibowo, M. E., \& Wagimin, W. (2017). Bimbingan Kelompok dengan Teknik Role Playing untuk Meningkatkan Self-Efficacy dan Harapan Hasil (Outcome Expectations) Karir Siswa. Jurnal Bimbingan Konseling, 6(1), 49-53.

Hafiun, M. (2017). Zuhud dalam Ajaran Tasawuf. Hisbah: Jurnal Bimbingan Konseling dan Dakwah Islam, 14(1), 77-93.

Hamka, H. (2000). Tasawuf Modern. Jakarta: Panjimas.

Irawan, E. (2013). Efektivitas Teknik Bimbingan Kelompok Untuk Meningkatkan Konsep Diri Remaja (Studi Pre-Eksperimen Pada Siswa Kelas X SMK Yapema Gadingrejo Lampung). PSIKOPEDAGOGIA Jurnal Bimbingan dan Konseling, 2(1), 44-54.

Jannati, Z., \& Indri M., D. B. (2019). Bimbingan Kelompok Berbantuan Al-qur'an: Sebuah Solusi Peningkatan Kecerdasan Emosi Mahasiswa Bimbingan dan Penyuluhan Islam. Bulletin of Counseling and Psychotherapy, 1(1), 19-28.

Maknin, K., \& Afifah, N. (2011). Konsep dan Implementasi Zuhud dalam Pemenuhan Kebutuhan Primer Santri (studi pada beberapa pesantren tradisional dan modern di Kabupaten Malang). Progresiva, 5(1), 162666.

Mukhsin, R., Mappigau, P., \& Tenriawaru, A. N. (2017). Pengaruh Orientasi Kewirausahaan Terhadap Daya Tahan Hidup Usaha Mikro Kecil dan Menengah Kelompok Pengolahan Hasil Perikanan di Kota Makassar. Jurnal Analisis, 6(2), 188-193.

Mulyadi, M. (2011). Penelitian kuantitatif dan kualitatif serta pemikiran dasar menggabungkannya. Jurnal studi komunikasi dan media, 15(1), 128-137.

Prabowo, A., \& Heriyanto, H. (2013). Analisis pemanfaatan buku elektronik (e-book) oleh pemustaka di perpustakaan SMA Negeri 1 Semarang. Jurnal IImu Perpustakaan, 2(2), 152-161.

Ridhani, A. R., \& Sutoyo, A. (2016). Pengembangan Model Bimbingan Kelompok Berbasis Islam Untuk Meningkatkan Perilaku Etik Berkomunikasi Siswa MTs Kota Banjarmasin. Jurnal Bimbingan Konseling, 5(1), 55-64.

Saripah, T., Mulyana, Y., \& Kamaludin, U. A. (2017). Fungsi Zuhud Terhadap Ketenangan Jiwa (Studi Analisis terhadap Tafsir Jailani Karya Abd al-Qadir Jailāni). Al-Bayan: Jurnal Studi Ilmu AlQur'an dan Tafsir, 2(2), 132-146.

Sumantri, L., Rangka, I. B., \& Fahmi, R. N. (2017). Layanan Bimbingan Kelompok Untuk Membina Self Efficacy Siswa. INSIGHT: Jurnal Bimbingan Konseling, 6(2), 156-164.

Sutoyo, A. (2012). Pemahaman individu. Yogyakarta: Pustaka Pelajar.

Tasbih, T. (2011). Analisis Historis Sebagai Instrumen Kritik Matan Hadis. Al-Ulum, 11(1), 151-172.

Wahid, A. W. A. (2017). Karakteristik Sifat Zuhud Menurut Hadis Nabi SAW. Jurnal IImiah AlMu'ashirah, 13(1), 66-87. 